\title{
PENGARUH NILAI CBR TANAH DASAR DAN MUTU BETON TERHADAP TEBAL PELAT PERKERASAN KAKU METODE BINA MARGA
}

\author{
Ni Luh Putu Shinta ${ }^{1}$, Widodo Kushartomo ${ }^{2}$, Mikhael Varian ${ }^{3}$ \\ ${ }^{1}$ Program Studi Teknik Sipil Fakultas Teknik Universitas Tarumanagara \\ shintarachmat@yahoo.com \\ ${ }^{2}$ Program Studi Teknik Sipil Fakultas Teknik Universitas Tarumanagara \\ widodo@untar.ac.id \\ ${ }^{3}$ Program Studi Teknik Sipil Fakultas Teknik Universitas Tarumanagara
}

\begin{abstract}
ABSTRAK
Untuk menentukan tebal pelat Perencanaan perkerasan kaku memerlukan beberapa parameter seperti nilai CBR tanah dasar, mutu beton, dan beban lalu lintas. Kondisi di lapangan dalam setiap seksi panjang jalan seringkali memiliki nilai CBR yang berbeda, ini berdampak pada perencanaan sehingga membutuhkan waktu cukup lama dalam menghitung tebal pelat. Proses perhitungan juga membutuhkan waktu dan ketelitian jika dilakukan secara manual. Penelitian ini menggunakan parameter tanah dasar dari nilai: CBR 3\% sampai dengan 11\%, dan mutu beton yang digunakan dalam perencanaan adalah K200, K225, K250, K275 dan K300. Penelitian menghasilkan metode yang lebih sederhana untuk merencanakan suatu perkerasan kaku yaitu dengan mempergunakan grafik hubungan antara nilai CBR, mutu beton, dan tebal pelat beton untuk menentukan tebal pelat yang dibutuhkan. Grafik diperoleh berdasarkan metode Bina Marga 2002 dan telah divalidasi dengan tingkat keakuratan yang cukup signifikan.
\end{abstract}

Kata kunci : Perkerasan, CBR, beton, pelat, Bina Marga.

\section{PENDAHULUAN}

Jalan adalah prasarana utama dari transportasi darat, bagi setiap lalu lintas dari satu tempat menuju ke tempat lainnya. Sehingga, kondisi jalan sangat berpengaruh pada keamanan dan kenyamanan setiap pengguna jalan, Oleh karena itu, tahapan perencanaan suatu perkerasan jalan sangatlah penting. Perencanaan harus mempertimbangkan faktor ekonomi, lingkungan, sifat tanah dasar, beban lalu-lintas, fungsi jalan dan faktor-faktor lainnya.

Perencanaan perkerasan jalan yang digunakanpun berkembang terus seiring berkembangnya ilmu pengetahuan dan teknologi. Diawali dengan perkerasan batu pecah dan batu belah. Saat ini penelitian tentang perencanaan perkerasan jalan maju sangat pesat seiring dengan bertambahnya jenis dan jumlah kendaraan. Sehingga mendesain jalan yang aman dan nyaman pun menjadi prioritas utama. Jenis perkerasan yang umum dipergunakan yaitu : perkerasan lentur/aspal (flexible pavement), perkerasan kaku/beton (rigid Pavement), dan perkerasan komposit (composite pavement).

Perkerasan Kaku adalah suatu susunan konstruksi perkerasan di mana lapisan atasnya menggunakan pelat beton yang terletak di atas pondasi atau langsung di atas tanah dasar. Pada perkerasan kaku/beton (rigid pavement) biaya yang digunakan relatif lebih mahal karena menggunakan pelat beton sebagai lapisan atas. Beton memiliki sifat tahan terhadap air maupun suhu tinggi sehingga pemeliharaan yang dilakukan terhadap jalan yang menggunakan perkerasan kaku dilakukan dalam rentang waktu yang lebih lama.

Merencanakan perkerasan kaku dapat mempergunakan beberapa metode, salah satunya ialah metode Bina Marga 2002, karena metode tersebut dapat memfasilitasi perencanaan perkerasan kaku. Metode Bina Marga sendiri membutuhkan beberapa parameter dalam perhitungannya, salah satunya ialah parameter tanah dasar yang ditentukan oleh nilai CBR (California Bearing 
Ratio). Nilai CBR tanah dasar sangat menentukan tebal lapis perkerasan kaku yang akan direncanakan. Jadi hal ini untuk membantu merencanakan perkerasan kaku dengan lebih efisien untuk dapat memperkirakan tebal pelat pada perkerasan kaku secara cepat, dengan tujuan menyajilan grafik hubungan antara nilai CBR, mutu beton, dan tebal pelat beton perkerasan kaku dengan metode Bina Marga 2002.

\section{METODOLOGI}

Penelitian ini dilakukan dengan menghitung tebal pelat perkerasan kaku berdasarkan nilai CBR dan mutu beton menggunakan metode Bina Marga 2002. Sehubungan dengan itu, maka nilai CBR dan mutu beton yang digunakan serta persyaratannya ditentukan sebagai berikut:

1. Parameter tanah dasar dari nilai: CBR 3\% sampai dengan $11 \%$.

2. Mutu beton yang digunakan K200, K225, K250,K275 dan K300.

3. Lalu lintas harian rata-rata (LHR) diperoleh pada ruas jalan Laksamana RE Martadinata.(Balai Besar Jalan Nasional IV)

4. Pondasi bawah yang digunakan adalah $100 \mathrm{~mm}$ Campuran Beton Kurus (CBK) atau 150mm Beton Pondasi (BP).

Berdasar CBR rencana, dapat diketahui CBR efektif, dari mutu beton dapat mencari fcf, serta dari data LHR dapat diperoleh JSKN, dilanjutkan perhitungan repetisi sumbu rencana dan terakhir adalah taksir tebal pelat berdasarkan analisa fatik dan erosinya, setelah menghitung semua tebal pelat, maka dapat dibuat sebuah grafik hubungan nilai CBR, mutu beton, dan tebal pelat perkerasan kaku. Grafik tersebut harus divalidasi agar dapat digunakan di kemudian hari.

\section{HASIL DAN ANALISIS}

Hitungan tebal pelat berdasarkan nilai CBR dan mutu beton pada lalulintas di jalana Laksamana RE Martadinata disajikan pada tabel 1 sampai dengan tabel 5 berikut ini.

Tabel 1. Tebal Pelat Beton Pada Perhitungan Mutu Beton K200

\begin{tabular}{lllll}
\hline No & $\begin{array}{l}\text { Mutu } \\
\text { Beton }\end{array}$ & $\begin{array}{l}\text { CBR } \\
\text { rencana } \\
(\%)\end{array}$ & $\begin{array}{l}\text { CBR } \\
\text { efektif } \\
(\%)\end{array}$ & $\begin{array}{l}\text { Tebal } \\
\text { Pelat } \\
(\mathrm{cm})\end{array}$ \\
\hline 1 & K200 & 3 & 20 & 30 \\
\hline 2 & K200 & 4 & 30 & 29 \\
\hline 3 & K200 & 5 & 35 & 28.5 \\
\hline 4 & K200 & 6 & 40 & 28 \\
\hline 5 & K200 & 7 & 50 & 27.5 \\
\hline 6 & K200 & 8 & 55 & 27.25 \\
\hline 7 & K200 & 9 & 65 & 27 \\
\hline 8 & K200 & 10 & 70 & 27 \\
\hline 9 & K200 & 11 & 75 & 27 \\
\hline
\end{tabular}


Tabel 2. Tebal Pelat Beton Pada Perhitungan Mutu Beton K225

\begin{tabular}{lllll}
\hline No & $\begin{array}{l}\text { Mutu } \\
\text { Beton }\end{array}$ & $\begin{array}{l}\text { CBR } \\
\text { rencana } \\
(\%)\end{array}$ & $\begin{array}{l}\text { CBR } \\
\text { efektif } \\
(\%)\end{array}$ & $\begin{array}{l}\text { Tebal } \\
\text { Pelat } \\
(\mathrm{cm})\end{array}$ \\
\hline 1 & K225 & 3 & 20 & 29 \\
\hline 2 & K225 & 4 & 30 & 28 \\
\hline 3 & K225 & 5 & 35 & 27.5 \\
\hline 4 & K225 & 6 & 40 & 27 \\
\hline 5 & K225 & 7 & 50 & 26.5 \\
\hline 6 & K225 & 8 & 55 & 26,25 \\
\hline 7 & K225 & 9 & 65 & 26 \\
\hline 8 & K225 & 10 & 70 & 26 \\
\hline 9 & K225 & 11 & 75 & 26 \\
\hline
\end{tabular}

Tabel 3. Tebal Pelat Beton Pada Perhitungan Mutu Beton K250

\begin{tabular}{lllll}
\hline No & $\begin{array}{l}\text { Mutu } \\
\text { Beton }\end{array}$ & $\begin{array}{l}\text { CBR } \\
\text { rencana } \\
(\%)\end{array}$ & $\begin{array}{l}\text { CBR } \\
\text { efektif } \\
(\%)\end{array}$ & $\begin{array}{l}\text { Tebal } \\
\text { Pelat } \\
(\mathrm{cm})\end{array}$ \\
\hline 1 & K250 & 3 & 20 & 28 \\
\hline 2 & K250 & 4 & 30 & 27 \\
\hline 3 & K250 & 5 & 35 & 26.5 \\
\hline 4 & K250 & 6 & 40 & 26 \\
\hline 5 & K250 & 7 & 50 & 25.5 \\
\hline & K250 & 8 & 55 & 25.25 \\
\hline & K250 & 9 & 65 & 25 \\
\hline & K250 & 19 & 70 & 25 \\
\hline & K250 & 11 & 75 & 25 \\
\hline
\end{tabular}

Tabel 4. Tebal Pelat Beton Pada Perhitungan Mutu Beton K275

\begin{tabular}{lllll}
\hline No & $\begin{array}{l}\text { Mutu } \\
\text { Beton }\end{array}$ & $\begin{array}{l}\text { CBR } \\
\text { rencana } \\
(\%)\end{array}$ & $\begin{array}{l}\text { CBR } \\
\text { efektif } \\
(\%)\end{array}$ & $\begin{array}{l}\text { Tebal } \\
\text { Pelat } \\
(\mathrm{cm})\end{array}$ \\
\hline 1 & K275 & 3 & 20 & 27 \\
\hline 2 & K275 & 4 & 30 & 26.526 \\
\hline 3 & K275 & 5 & 35 & 25.5 \\
\hline 4 & K275 & 6 & 40 & 25 \\
\hline 5 & K275 & 7 & 50 & 24.75 \\
\hline 6 & K275 & 8 & 55 & 24.5 \\
\hline 7 & K275 & 9 & 65 & 24.25 \\
\hline 8 & K275 & 19 & 70 & 24,25 \\
\hline 9 & & 11 & 75 & 24.25 \\
\hline
\end{tabular}


Tabel 5. Tebal Pelat Beton Pada Perhitungan Mutu Beton K300

\begin{tabular}{lllll}
\hline No & $\begin{array}{l}\text { Mutu } \\
\text { Beton }\end{array}$ & $\begin{array}{l}\text { CBR } \\
\text { rencana } \\
(\%)\end{array}$ & $\begin{array}{l}\text { CBR } \\
\text { efektif } \\
(\%)\end{array}$ & $\begin{array}{l}\text { Tebal } \\
\text { Pelat } \\
(\mathrm{cm})\end{array}$ \\
\hline 1 & K300 & 3 & 20 & 26 \\
\hline 2 & K300 & 4 & 30 & 25.5 \\
\hline 3 & K300 & 5 & 35 & 25 \\
\hline 4 & K300 & 6 & 40 & 24.5 \\
\hline 5 & K300 & 7 & 50 & 24 \\
\hline 6 & K300 & 8 & 55 & 23.75 \\
\hline 7 & K300 & 9 & 65 & 23.5 \\
\hline 8 & K300 & 10 & 70 & 23.5 \\
\hline 9 & K300 & 11 & 75 & 23.5 \\
\hline
\end{tabular}

Perkerasan kaku, terdiri atas pelat (slab) beton sebagai lapis pondasi dan lapis pondasi bawah (jika diperlukan) di atas tanah dasar. Kondisi dari lapisan Perkerasan kaku sangat tergantung dari sambungan pada pelat dan pondasi bawah yang dipergunakan. Penggunaan pondasi bawah akan sangat berpengaruh terhadap karakteristik perkerasan yaitu : durabilitas, ketidakrataan dan kekakuan.( Zhou, 2015).

Lapis pondasi bawah jika digunakan di bawah pelat beton karena beberapa pertimbangan, yaitu antara lain untuk menghindari terjadinya pumping, kendali terhadap drainase,dan terhadap kembang-susut yang terjadi pada tanah dasar dan untuk menyediakan lantai kerja (working platform) untuk pekerjaan konstruksi dan untuk stabilisasi.

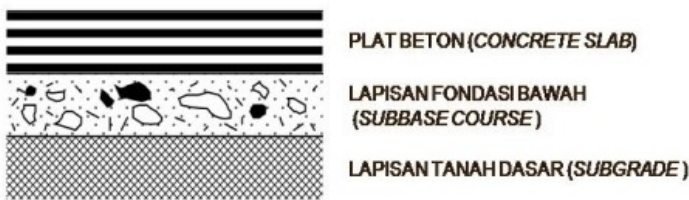

Gambar 1. Susunan lapisan perkerasan kaku (Bowles, 1986)

Perkerasan beton yang kaku dan memiliki modulus elastisitas tinggi, akan mendistribusikan beban ke bidang tanah dasar yang cukup luas sehingga bagian terbesar dari kapasitas struktur perkerasan diperoleh dari plat beton sendiri, untuk penentuan beban lalu lintas rencana pada perkerasan kakudinyatakan dalam jumlah sumbu kendaraan niaga sesuai dengan konfigurasi sumbu pada lajur rencana selama umur rencana. Beban Lalulintas menggunakan data terakhir. Untuk kendaraan yang ditinjau memiliki berat total minimum 5 ton. Konfigurasi sumbu untuk perencanaan terdiri atas 4 jenis kelompok sumbuyaitu: umbu tunggal roda tunggal (STRT),Sumbu tunggal roda ganda (STRG),Sumbu tandem roda ganda (STdRG) dan Sumbu tridem roda ganda (STrRG). Koefisien distribusi berdasarkan lajur rencana.Lajur rencana maka jumlah lajur dan koefsien distribusi kendaraan niaga dapat ditentukan dari lebar perkerasan.

Merencanaan suatu jalan, faktor yang penting untuk diketahui adalah kondisi tanah dasar dilokasi tersebut. Menurut American Association of State Highway and Transportation 
Vol. 1, No. 1, April 2017: hlm 244-250

(AASHTO), tanah merupakan campuran dari partikel-partikel yang terdiri dari salah satu atau seluruh jenis berikut:

1. Kerikil (Gravel) partikel batuan yang berukuran $76,2 \mathrm{~mm}-2 \mathrm{~mm}$.

2. Pasir (Sand) berukuran $2 \mathrm{~mm}-0,075 \mathrm{~mm}$.

3. Lanau (Silt) berukuran 0,075 $\mathrm{mm}-0,002 \mathrm{~mm}$. Lempung (colloids) partikel mineral diam, berukuran $<0,002 \mathrm{~mm}$.

Partikel-partikel tanah di setiap tempat berbeda, maka dari itu kekuatan tanah pun tidaklah sama antara satu tempat dan tempat lainnya.

Tanah dasar merupakan kunci keberhasilan dari perancangan tebal perkerasan yang homogen dan mencegah terjadinya diversifikasi yang sangat tinggi dan berakibat kepada heterogennya struktur perkerasan. (Tuleubekov, 2014)

Kekuatan tanah dasar dinyatakan dalam CBR (California Bearing Ratio) (Bowles, 1986). Nilai CBR tanah akan menentukan ketebalan lapis keras yang akan dibuat di atasnya, daya dukung tanah ditentukan oleh CBR insitu sesuai dengan SNI 03-1731-1989 atau CBR Laboratorium sesuai dengan SNI 03-1744-1989, masing - masing untuk perencanaan tebal perkerasan lama dan perkerasan jalan baru. Pada awal rekayasa jalan raya, pelat perkerasan kaku dibangun langsung di atas tanah dasar tanpa memperhatikan sama sekali jenis tanah dasar dan kondisi drainasenya (Suprapto, 1994). Dengan bertambahnya beban lalu-lintas, mulai disadari bahwa jenis tanah dasar berperan penting terhadap kinerja perkerasan, terutama sangat pengaruh terhadap terjadinya pumping. Maka dikembangkanlah pondasi bawah yang menjadi lapisan dibawah permukaan atau dibawah pelat beton. Menurut Bowles (1986), secara lebih spesifik, fungsi dari lapis pondasi bawah adalah:

1. Menyediakanlapisan yang seragam, stabil dan permanen. menjadi modulus reaksi gabungan (modulus of composite reaction) $\mathrm{k}$ gabungan.

2. Mengurangi kemungkinan terjadinya retak-retak pada plat beton

3. Menghindari terjadinya pumping

Kekuatan beton harus dinyatakan dalam nilai kuat tarik uji lentur (flexural, strength) umur 28 hari, yang didapat dari hasil pengujian balok dengan pembebanan tiga titik (ASTM C-78) yang besarnya secara tipikal sekitar 3-5 MPa $\left(30-50 \mathrm{~kg} / \mathrm{cm}^{2}\right)$. Beton juga bisa diperkuat dengan serat baja (steel fiber) untuk memperkuat kuat tarik lenturnya serta mengendalikan retak pada plat khususnya jika bentuk tak lazim.

Tebal pelat taksiran dipilih dan total fatik serta kerusakan erosi dihitung berdasarkan komposisi lalu-lintas selama umur rencana. Jika kerusakan fatik atau erosi lebih dari 100\%, tebal taksiran dinaikan dan proses perencanaan diulangi. Tebal rencana adalah tebal taksiran yang terkecil yang mempunyai total fatik dan atau total kerusakan erosi lebih kecil atau sama dengan $100 \%$. (Bina Marga, 2003).

Prosedur perencanaan perkerasan beton semen didasarkan atas dua model kerusakan yaitu, retak fatique (lelah) tarik lentur pada pelat dan erosi pada pondasi bawah yang diakibatkan oleh lendutan berulang pada sambungan dan tempat retak yang direncanakan. Prosedur ini mempertimbangkan ada tidaknya ruji pada sambungan atau bahu beton. Perkerasan beton semen menerus dengan tulangan dianggap sebagai perkerasan bersambung yang dipasang ruji. (Bina Marga, 2003). 
Tebal rencana adalah tebal taksiran yang paling kecil yang mampunyai total tarik dan atau total kerusakan erosi lebih kecil atau sama dengan 100\%. (Jaya, 2016).

Berdasarkan hasil perhitungan yang disajikan dalam tabel 1 sampai dengan tabel, dapat dibuat grafik hubungan antara nilai CBR, mutu beton, dan tebal pelat beton perkerasan kaku.

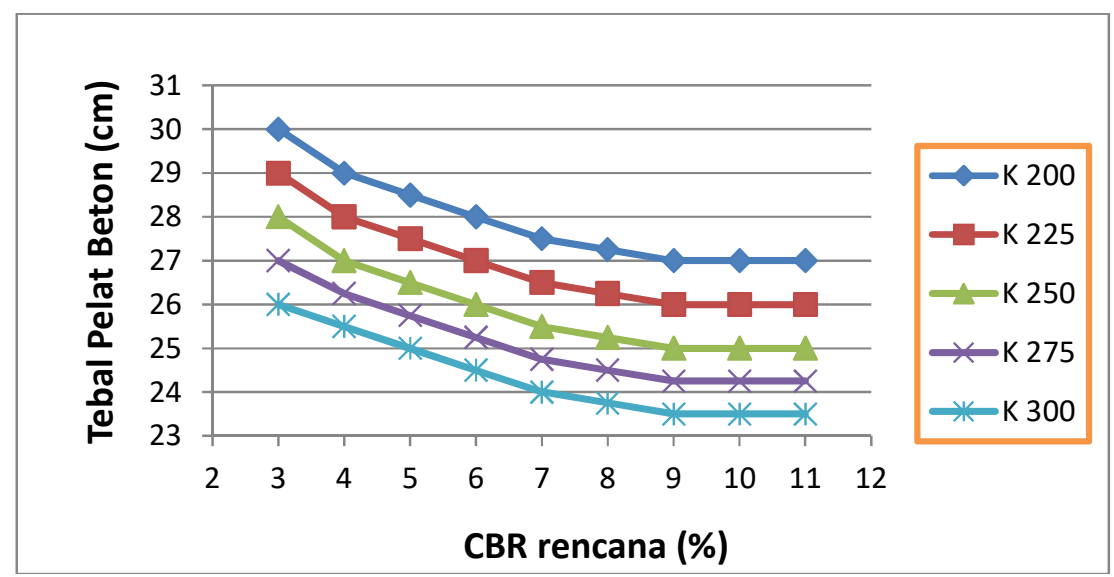

Gambar 2. Grafik hubungan CBR, mutu beton, dan tebal pelat beton.

Grafik pada Gambar 2 memperlihatkan, ketebalan pelat beton akan semakin menipis bila mutu beton semakin meningkat, demikian juga dengan nilai CBR tanah, semakin besar prosentase nilai CBR maka tebal pelat beton untuk pelapisan perkerasan kaku juga semakin tipis. Seluruh rencana perhitungan telah menggunakan metode Bina marga 2003 dan memenuhi standar minimum untuk perhitunagn fatique Tarik lentur dan erosi pada pelat bawah. Bedasarkan grafik yang ditampilkan dalam Gambar 2 tersebut, maka akan dengan cepat dan mudah dapat di tentukan tebal perkerasan lapisan kaku yang di butuhkan jika telah diketahui nilai CBR dan mutu beton yang diperlukan.

\section{KESIMPULAN}

Berdasarkan analisis grafik dan perhitunganyang dilakukan, maka dapat diambil kesimpulan sebagai berikut :

1. Tebal pelat beton dipengaruhi oleh mutu beton, semakin tinggi mutu beton maka tebal pelat yang dibutuhkan akan semakin tipis.

2. Mutu beton K200 kerusakan yang terjadi lebih ditentukan oleh kerusakan fatik terlebih dahulu, sedangkan pada K300 kerusakan yang terjadi ditentukan oleh erosi terlebih dahulu.

3. Tebal pelat beton juga dipengaruhi oleh nilai CBR tanah dasar, semakin besar nilai CBR maka tebal pelat beton yang digunakan akan semakin tipis.

4. Penggunaan grafik pada Gambar 2 hanya berlaku jika bahan pondasi bawah yang dipilih adalah $100 \mathrm{~mm}$ Campuran Beton Kurus atau $150 \mathrm{~mm}$ Bahan Pengikat dengan angka JSKN $\leq$ $6.9 \times 10^{7}$. Apabila angka JSKN diatas $6.9 \times 10^{7}$ maka grafik ini tidak dapat dijadikan acuan. 


\section{REFERENSI}

AASHTO. (1993). "Guide for Design of Pavement Structures", Washington DC.

Balai Besar Pelaksanaan Jalan Nasional IV. (2005). "Detailed Engineering Design and Construction Supervision of Tanjung Priok Access Road Construction Project, phase 1". Jakarta.

Bowles, E. Joseph. (1986). "Sifat-sifat Geoteknis Tanah (Mekanika Tanah), Erlangga, Jakarta.

Direktorat Jenderal Bina Marga. (2003). "Perencanaan Perkerasa Jalan Beton Semen (Pd T-142003)".BSN

Suprapto. (1994). "Bahan dan Struktur Jalan Raya", Biro Penerbit Teknik Sipil UGM, Yogyakarta.

Tuleubekov, K. (2014). "Corelation between Subgrade Reaction Modulus and CBR for Airport Pavement Subgrades", T\&DI Congress ASCE.

Zhou, Wujun. (2015). "Evaluation of Pavement Support for Pavement Design", J Transport Eng. ASCE.

Jaya, Fery Hendi. (2016). “Analisis Rancangan Perbandingan Metode (Bina Marga Dan AASHTO 1993) Konstruksi Perkerasan Jalan Beton Dengan Lapis Tambahan Pada Kondisi Existing", Tapak Vol.5 No.2. ISSN 2089-2098. Bandar Lampung. 